\title{
Al-Qur'an Views Relating to Environmental Conservation
}

\author{
Ariyadi, SHI, MH. \\ Dosen Tetap Yayasan Universitas Muhammadiah Palangkaraya \\ Email :Ariyadialbanjari@gmail.com
}

\begin{abstract}
Allah SWT has created a variety of nature on this earth. The plant that God created with various benefits. Wrong is for human needs. Humans as God's creatures also need plants for them. In fact the essence is the most perfect worshiper of God, but they will still need the plant. The universe is the greatest gift to man, for that Allah Almighty enjoined man to make good use of it and we must continue to give thanks to Him. In reality, however, there is corruption here and there from the actions of the hypocrites.

Human beings as perfect beings who are mind-wielded by God should use their reason for everything good for themselves and for others. Including plant or tree maintenance for the sake of their environmental sustainability. In addition we also should not neglect the land because the land can be used for something good. the environment taught by Rasullloh SAW based on revelation, so many we encounter scientific verses of the Qur'an that discusses the environment. The Qur'anic messages about the environment are very clear and prospective.

This authors' journal will try to discuss extensively about al-quran and the environment, since al-qur'an has explained the importance of safeguarding the environment by laying its foundations and principles globally. Purpose of problem First: Knowing what and how the current environmental condition. Second: Knowing how important it is to maintain and maintain the environment. Third: Know how to keep the environment as it is in al-qur'an.
\end{abstract}

\section{Keywords : Al-Qur'an, Environmental, Conservation}

\begin{abstract}
Abstrak
Allah SWT telah menciptakan berbagai makhluk di bumi ini. Termasuk tumbuhan yang mana Allah menciptakannya dengan berbagai manfaat. Salah satunya adalah untuk memenuhi kebutuhan manusia. Manusia sebagai makhluk Tuhan juga pastinya membutuhkan tumbuhan untuk memenuhi kepentingan mereka. Walaupun hakikatnya mereka adalah makhluk Tuhan yang paling sempurna, akan tetapi mereka akan tetap membutuhkan tumbuhan tersebut.Alam semesta merupakan karunia yang paling besar terhadap manusia, untuk itu Allah swt menyuruh manusia untuk memanfaatkannya dengan baik dan kita harus terus bersyukur kepada-Nya. Akan tetapi, pada kenyataanya lain justru terjadi kerusakan di sana sini akibat perbuatan orang-orang munafiq.

Manusia sebagai makhluk sempurna yang dikarunai akal oleh Allah swt sudah seharusnya menggunakan akal mereka untuk segala sesuatu yang baik bagi dirinya dan juga orang lain. Termasuk memelihara tanaman atau pohon demi kelestarian lingkungan hidup mereka. Selain itu kita juga tidak boleh menelantarkan lahan karena lahan tersebut dapat dimanfaatkan untuk sesuatu yang
\end{abstract}


baik. lingkungan yang diajarkan oleh Rasullloh SAW berdasarkan wahyu, sehingga banyak kita jumpai ayat-ayat ilmiah Al-Qur'an yang membahas tentang lingkungan. Pesan-pesan Al-Qur'an mengenai lingkungan sangat jelas dan prospektif.

Jurnal ini penyusun akan mencoba membahas secara luas mengenai al-qur'an dan lingkungan, karena al-qur'an telah menjelaskan tentang pentingnya menjaga lingkungan dengan meletakkan dasar dan prinsipnya secara global.Tujuan masalah Pertama: Mengetahui apa dan bagaimana kondisi lingkungan saat ini. Kedua: Mengetahui betapa pentingnya menjaga dan memelihara lingkungan. Ketiga: Mengetahui bagaimana cara menjaga lingkungan seperti yang terdapat pada al-qur'an.

\section{Keywords : Al-Qur'an, Environmental, Conservation}

\section{PENDAHULUAN}

\section{Latar Belakang}

Salah satu permasalahan pada masa

kini adalah permasalahan lingkungan

hidup, ${ }^{1}$ dewasa ini telah menjadi isu global

karena menyangkut berbagai sektor dan

berbagai kepentingan umat

manusia. Tentunya hal ini terbukti dengan

munculnya isu-isu kerusakan lingkungan

yang semakin santer terdengar.

Diantaranya isu yang paling menonjol

ialah efek rumah kaca, lapisan ozon

1 Husein, Harun M. Lingkungan hidup: masalah pengelolaan dan penegakan hukumnya. Bumi Aksara, 1993. Dan Achmad, Rukaesih. "Kimia lingkungan." (2011): 1-34. yang menipis, kenaiakan suhu udara, mencairnya es di kutub, dll. ${ }^{2}$

Timbulnya kerusakan alam atau lingkungan hidup sebagian besar adalah hasil perbuatan manusia. Karena manusialah yang diberi tanggung jawab sebagai khalifah di bumi. Manusia mempunyai daya inisiatif dan kreatif, sedangkan makhluk-makhluk lainnya tidak memilikinya. Kebudayaan manusia makin lama makin maju sesuai dengan perkembangan dan kemajuan ilmu pengetahuan dan teknologi. Sejalan dengan kemajuan tersebut, perkembangan persenjataan dan alat perusak

${ }^{2}$ Irianto, I. Ketut. "Ilmu Lingkungan." (2016).dan Hadi, Sudharto P. Manusia Dan Lingkungan. Badan Penerbit, Universitas Diponegoro, 2000. Serta Sururi, Ahmad. "Menggapai Pelestarian Lingkungan Hidup Di Indonesia: Studi Perbandingan Etika Islam Dan Etika Ekofeminisme." Fikrah 2.1 (2015). 
lingkungan makin maju pula. $^{3}$ Kerusakan lingkungan diperparah lagi dengan banyaknya kendaraan bermotor, dan pabrik-pabrik yang menimbulkan pencemaran udara atau polusi. ${ }^{4}$ Pencemaran tersebut membahayakan keselamatan hidup manusia dan kehidupan sekelilingnya. Limbah-limbah pabrik sering kali dibuang seenaknya ke sungai yang akhirnya bermuara ke laut. Demikian pula kapal-kapal tanker yang membawa minyak sering mengalami kebocoran, sehinggga minyaknya tumpah ke laut. Akibatnya, air sungai dan laut beracun yang menyebabkan mati atau tercemarnya ikan dengan zat beracun. ${ }^{5}$

Mungkin selama ini manusia terlau jumawa dengan kemampuan yang mereka miliki untuk mengolah lingkungan yang ada. Padahal seharusnya manusia sebagai makhluk yang dimuliakan dengan akal, seharusnya mampu berbuat apapun asalkan tetap memegang amanah dan tanggung jawab dalam mengolah bumi. Seharusnya

${ }^{3}$ Fauziati, Rini. Relevansi Kandungan AlQur'an Surat Ar-Rum Ayat 41 Dengan Pelestarian Lingkungan Pada Mapel Biologi Materi

4 Suaryana, Agung. "Implementasi akuntansi sosial dan lingkungan di Indonesia." Jurnal Ilmiah Akuntansi dan Bisnis (2011). Dan Siregar, Edy Batara Mulya. "Pencemaran udara, respon tanaman dan pengaruhnya pada manusia." Pencemaran Udara, Respon Tanaman Dan Pengaruhnya Pada Manusia (2005).

${ }^{5}$ Ibit kita sebagai umat Islam kembali kepada ajaran Al-qur'an dalam hal mengolah lingkungan. Supaya kita dapat lebih bijak dan bertanggung jawab. Sehingga nantinya dengan sendirinya akan lahirlah prinsip pembangunan berkelanjutan atau pembangunan berwawasan lingkungan. ${ }^{6}$

\section{METODE PENELITIAN}

Penelitian inibertujuan untuk mengetahui bagaimana peran agama Islam dalam Pelestarian Lingkungan. Dengan demikian, setidaknya yang selama ini menjadi titik masalah dapat terungkap dan dapat menjadi informasi ilmiah yang mencerahkan.

Penelitian ini merupakan penelitian perpustakaan (Library research), penelitian ini bersifat deskriptif, dimana data-data yang dikumpulkn dianalisis secara kualitatif. Untuk memperoleh data yang diperlukan. Peneliti melakukan observasi keberbagai perpustakaan baik perpustakaan digital maupun perpustakaan yang ada di kota Palangka Raya.

\footnotetext{
${ }^{6}$ Sugandhy, Aca, And Rustam Hakim. Prinsip Dasar Kebijakan Pembangunan Berkelanjutan Berwawasan Lingkungan. Bumi Aksara, 2007. Dan Siahaan, Nommy Horas Thombang. Hukum Lingkungan Dan Ekologi Pembangunan. Erlangga, 2004.
} 


\section{HASIL DAN PEMBAHASAN}

A. Pandangan Al-Qur'an yang Berkaitan dengan Pelestarian Lingkungan

Al-Qur'an sebagai kitab suci agama Islam di dalamnya banyak terangkum ayatayat yang membahas mengenai lingkungan, seperti perintah untuk menjaga lingkungan, larangan untuk merusaknya, dll. Seperti yang akan di bahas berikut ini.

\section{Q.S. Ar-Rum ayat 41-42}

$$
\begin{aligned}
& \text { ظَهَرَ الْفَسَادُ فِي الْبَرِّ وَالْبَحْرِ بِمَا كَسَبَتْ أَنْدِي النَّاسِ }
\end{aligned}
$$

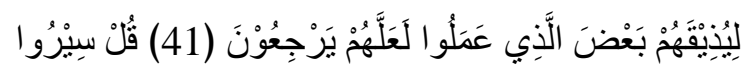

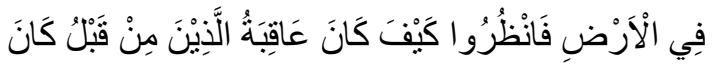

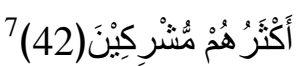

41. Telah tampak kerusakan di darat dan di laut disebabkan karena perbuatan tangan manusia,

supaya Allah merasakan kepada mereka sebagian dari (akibat) perbuatan mereka, agar mereka kembali (ke jalan yang benar). 42. Katakanlah "Adakanlah perjalanan di muka bumi dan perhatikanlah bagaimana kesudahan orang-orang yang terdahulu. Kebanyakan dari mereka itu adalah orangorang yang mempersekutukan (Allah)."8

\section{Kandungan Surat Ar-Rum 41-42}

Allah menciptakan Jin dan Manusia untuk beribadah kepada-NYA juga memberikan manusia kedudukan sebagai khalifah di bumi. Sebagai khalifah, manusia memiliki tugas memanfaatkan, mengelola dan memelihara.

Tetapi seringkali manusia lalai dengan kedudukannya sebagai khalifah di bumi. Pemanfaatan yang mereka lakukan terhadap alam seringkali tidak diiringi dengan usaha pelestarian. Keserakahan dan perlakuan buruk sebagian manusia terhadap alam justru mengakibatkan kerusakan dan kesengsaraan kepada manusia itu sendiri. Kerusakan terjadi di darat dan di laut seperti Banjir, tanah longsor, kekeringan, pencemaran air dan udara, dll.

Dalam ayat ini Allah menyuruh kita untuk melakukan perjalanan di muka bumi dan menengok kembali kisah-kisah umat terdahulu yang binasa karena ingkar kepada Allah SWT. Banyak kisahkisah orang terdahulu seperti cerita para nabi, sahabat-sahabat rasul dan tabi'in. Pada masa itu manusia juga banyak melakukan kerusakan di bumi. Sampai akhirnya Allah SWT. memusnahkannya. Usaha yang dapat kita lakukan untuk memelihara dan melestarikan lingkungan hidup diantaranya ; 
1. Rehabilitasi sumber daya alam berupa hutan, tanah, dan air yang rusak.

2. Pendayagunaan daerah pantai, wilayah laut, dan kawasan udara perlu dilanjutkan dan makin ditingkatkan tanpa merusak mutu dan kelestarian lingkungan hidup.

3. Membudidayakan tanaman dan hidup bersih .

"Kebersihan adalah sebagian dari iman ", maka rawatlah bumi ini dan sadarlah kita sebagai khalifah yang tugasnya untuk merawat, mengelola dan memanfaatkan apa yang ada di bumi ini.

\section{Q.S.Al-A'raf ayat 56-58}

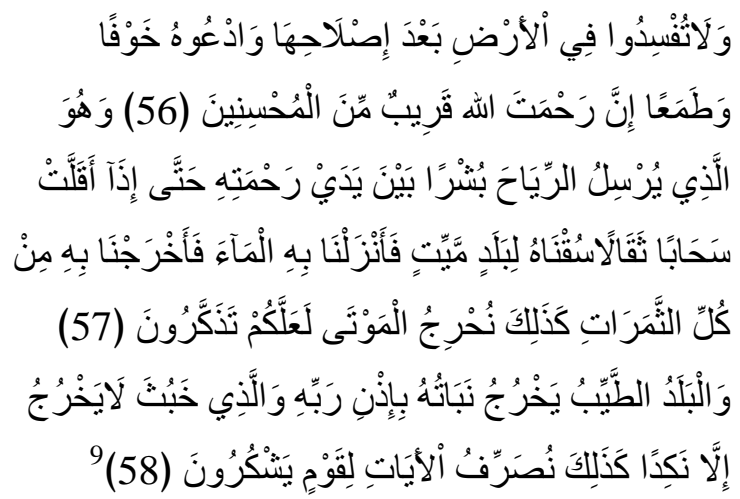

56. Dan janganlah kamu membuat kerusakan di muka bumi, sesudah (Allah) memperbaikinya dan berdoalah kepadaNya dengan rasa takut (tidak akan diterima) dan harapan (akan dikabulkan).

${ }^{9}$ Q.S.Al-A'raf Ayat 56-58
Sesungguhnya rahmat Allah amat dekat kepada orang-orang yang berbuat baik.

57. Dan dialah yang meniupkan angin sebagai pembawa berita gembira sebelum kedatangan rahmat-Nya (hujan); hingga apabila angin itu telah membawa angin mendung, kami halau ke suatu daerah yang tandus, lalu kami turunkan hujan di daerah itu, maka kami keluarkan dengan sebab hujan itu berbagai macam buah-buahan. Seperti itulah kami membangkitkan orangorang yang telah mati, mudah-mudahan kamu mengambil pelajaran.

58. Dan tanah yang baik, tanamantanamannya tumbuh subur dengan seizin allah; dan tanah yang tidak subur, tanaman-tanamannya hanya tumbuh merana. Demikianlah kami mengulangi tanda-tanda kebesaran (kami) bagi orangorang yang bersukur. ${ }^{10}$

\section{Isi Kandungan}

Bumi sebagai tempat tinggal dan tempat hidup manusia dan makhluk Allah lainnya sudah dijadikan Allah dengan penuh rahmat Nya. Gunung-gunung, lembah-lembah, sungai-sungai, lautan, daratan dan lain-lain semua itu diciptakan Allah untuk diolah dan dimanfaatkan dengan sebaik-baiknya oleh manusia, bukan sebaliknya dirusak dan dibinasakan

\footnotetext{
${ }^{10}$ Q.S.Al-A'raf Ayat 56-58
} 
Hanya saja ada sebagian kaum yang berbuat kerusakan di muka bumi. Mereka tidak hanya merusak sesuatu yang berupa materi atau benda saja, melainkan juga berupa sikap, perbuatan tercela atau maksiat serta perbuatan jahiliyah lainnya. Akan tetapi, untuk menutupi keburukan tersebut sering kali merka menganggap diri mereka sebagai kaum yang melakukan perbaikan di muka bumi, padahal justru merekalah yang berbuat kerusakan di muka bumi

Allah SWT melarang umat manusia berbuat kerusakan dimuka bumi karena Dia telah menjadikan manusia sebagai khalifahnya. Larangan berbuat kerusakan ini mencakup semua bidang, termasuk dalam hal muamalah, seperti mengganggu penghidupan dan sumber-sumber penghidupan orang lain.

Allah menegasakan bahwa salah satu karunia besar yang dilimpahkan kepada hambanya ialah Dia menggerakkan angin sebagai tanda kedatangan rahmat Nya. Angin yang membawa awan tebal, di halau ke negeri yang kering dan telah rusak tanamannya karena tidak ada air, sumur yang menjadi kering karena tidak ada hujan, dan kepada penduduk yang menderita lapar dan haus. Lalu dia menurunkan hujan yang lebat di negeri itu sehingga negeri yang hampir mati tersebut menjadi subur kembali dan penuh berisi air. Dengan demikian, dia telah menghidupkan penduduk tersebut dengan penuh kecukupan dan hasil tanamantanaman yang berlimpah ruah.

\section{Q.S. Sad ayat 27}

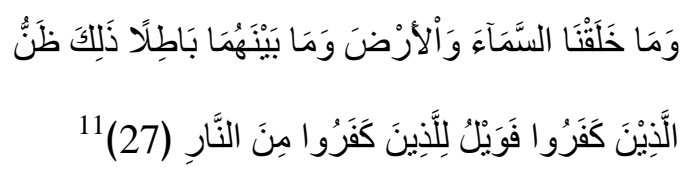

27. Dan kami tidak menciptakan langit dan bumi dan apa yang ada antara keduanya tanpa hikmah. Yang demikian itu adalah anggapan orang-orang kafir, maka celakalah orang-orang kafir itu karena mereka akan masuk neraka. ${ }^{12}$

\section{Isi Kandungan}

Allah SWT menjelaskan bahwa dia menjadikan langit, bumi dan makhluk apa saja yang berada diantaranya tidak sia-sia. Langit dengan segala bintang yang menghiasi, matahari yang memancarkan sinarnya di waktu siang, dan bulan yang menampakkan bentuknya yang berubahubah dari malam kemalam serta bumi tempat tinggal manusia, baik yang tampak dipermukaannya maupun yang tersimpan

\footnotetext{
${ }^{11}$ Q.S. Sad Ayat 27

${ }^{12}$ Q.S. Sad Ayat 27
} 
didalamnya, sangat besar artinya bagi kehidupan manusia. Kesemuanya itu diciptakan Allah atas kekuasaan dan kehendaknya sebagai rahmat yang tak ternilai harganya.

Allah memberikan pertanyaan pada manusia. Apakah sama orang yang beriman dan beramal saleh dengan orang yang berbuat kerusakan di muka bumi dan juga apakah sama antara orang yang bertakwa dengan orang yang berbuat maksiat? Allah SWT menjelaskan bahwa diantara kebijakan Allah ialah tidak akan menganggap sama para hambanya yang melakukan kebaikan dengan orang-orang yang terjerumus di lembah kenistaan. Allah SWT menjelaskan bahwa tidak patutlah bagi zat Nya dengan segala keagungan Nya, menganggap sama antara hamba-hambanya yang beriman dan melakukan kebaikan dengan orang-orang yang mengingkari keesaannya lagi memperturutkan hawa nafsu.

Mereka ini tidak mau mengikuti keesaan Allah, kebenaran wahyu, terjadinya hari kebangkitan dan hari pembalasan. Oleh karena itu, mereka jauh dari rahmat Allah sebagai akibat dari melanggar larangan-larangannya. Mereka tidak meyakini bahwa mereka akan dibangkitkan kembali dari dalam kuburnya dan akan dihimpun dipadang mahsyar untuk mempertanggung jawabkan perbuatannya sehingga mereka berani zalim terhadap lingkungannya.

Allah menciptakan langit dan bumi dengan sebenar-benarnya hanya untuk kepentingan manusia. Manusia diciptakan Nya untuk menjadi khalifah di muka bumi ini sehingga wajib untuk menjaga apa yang telah dikaruniakan Allah SWT.

Kandungan Surat Shaad ayat 27 dari segi artinya adalah :

"Dan Kami tidak menciptakan langit dan bumi dan apa yang ada antara keduanya tanpa hikmah."Pada firman ini Allah s.w.t menyatakan kepada Nabi Dawud a.s, bahwa sesungguhnya Allah telah menciptakan seisi bumi dan langit ini dengan penuh limpahan karunia. Tidak seperti apa yang dikatakan oleh para orang kafir terhadapnya (Dawud a.s).

"Yang demikian itu adalah anggapan orang - orang kafir."Pada firman ini Allah s.w.t menyatakan bahwa sesungguhnya apa yang dikatakan orang kafir terhadapnya itu adalah kebohong semata. Dikisahkan bahwa pada waktu itu orang - orang kafir berkata kepada Nabi Dawud a.s; bahwa Allah tidak pernah memberikan manfaat (karunia) apa pun kepada mereka (orang kafir) selama mereka hidup."Maka 
celakalah orang - orang kafir itu karena mereka akan masuk neraka."

Pada firman ini Allah memberikan (memperkuat) keyakinan Nabi Dawud a.s tentang kebohongan para orang - orang kafir tersebut. Dengan memberikan jaminan azab neraka atas mereka.

\section{KESIMPULANDAN SARAN}

\section{Kesimpulan}

Alloh menyebutkan secara eksplisit dalam Al-Qur'an tentang pentingnya lingkungan hidup dan cara-cara Islami dalam mengelola dunia ini.Kualitas sebagai indikator pembangunan dan ajaran Islam sebagai teknologi untuk mengelola dunia jelas merupakan pesan strategis dari Alloh SWT untuk diwujudkan dengan sungguhsungguh oleh setiap muslim.Adanya bencana lebih karena manusia melakukan ekspliotasi berdasarkan kemauan hawa nafsunya untuk memperoleh keuntungan yang sebanyak-banyaknya tanpa memikirkan bencana yang ditimbulkannya. Manusia tersebut tidak mempunyai pengetahuan mengenai ekosistem dan memandang baik perbuatannya yang salah tersebut tanpa pengetahuan, dalam AlQur'an disebutkan sebagai manusia yang dzalim. Sebagaimana Allah mengingatkan dalam Q.S Ar-Rum 30:29.

$$
\text { Bahaya yang diakibatkan }
$$
menurutkan kehendak nafsu sangat jelas dampaknya pada kehancuran bumi. Hal ini dapat berupa ekspliotasi yang berlebihan dan tidak memepertimbangkan daya dukung lingkungan, pemborosan, menguras sesuatu yang tidak penting dan tidak efisien, bermewah-mewahan dalam konsumsi dan gaya hidup dan seterusnya. Manusia yang melakukan cara seperti itu tentu mengelola bumi tanpa landasan dan petunjuk Al-Khalik sesuai dengan apa yang diisyaratkan kepadanya selaku hamba Tuhan. Syariat adalah fitrah di mana bumi hanya dapat diatur dengan ilmu syariatnya tersebut. Bila sesuatu menyalahi fitrah, maka akibatnya dapat terjadi kefatalan. Tanpa standar nilai-nilai syariat tersebut, manusia cenderung melihat kebenaran menurut hawa nafsu.

\section{Saran}

Islam mengajarkan agar umat manusia senantiasa menjaga lingkungan. Hal ini seringkali tercermin dalam beberapa pelaksanaan ibadah, seperti ketika menunaikan ibadah haji. Dalam haji, umat Islam dilarang menebang pohonpohon dan membunuh binatang. Apabila larangan itu dilanggar maka ia berdosa dan 
diharuskan membayar denda (dam). Lebih dari itu Allah SWT melarang manusia berbuat kerusakan di muka bumi.

Hendaknya kita sebagai umat Islam kembali kepada ajaran agama kita dalam mengolah lingkungan. Dengan adanya hal tersebut, seharusnya manusia menjadi lebih bijak dalam mengolah lingkungannya. Sehingga nantinya diharapkan apabila dalam kegiatan pengolahan lingkungan akan tumbuh pemahaman pembangunan berwawasan lingkungan maupun spirit pembangunan berkelanjutan.

Bukan tidak mungkin akan terealisasikan. Asalkan manusia mau kembali kepada ajaran agama yang utuh dan dapat memahaminya. Sehingga nantinya akan tumbuh kesadaran umat manusia dalam mengelola lingkungannnya. Sangat jelas dalam Al-Qur'an terdapat begitu banyaknya ayat-ayat yang membahas prosedur pengolahan alam yang bijak, perintah untuk tidak berbuat kerusakan di muka bumi,dll.

\section{DAFTAR PUSTAKA}

Achmad, Rukaesih. "Kimia lingkungan." (2011)

Husein, Harun M. Lingkungan hidup: masalah pengelolaan dan penegakan hukumnya. Bumi Aksara, 1993.
Hadi, Sudharto P. Manusia Dan Lingkungan. Badan Penerbit, Universitas Diponegoro, 2000.

Irianto, I. Ketut. "Ilmu Lingkungan." (2016)

Sururi, Ahmad. "Menggapai Pelestarian Lingkungan Hidup Di Indonesia: Studi Perbandingan Etika Islam Dan Etika Ekofeminisme." Fikrah 2.1 (2015).

Fauziati, Rini. Relevansi Kandungan AlQur'an Surat Ar-Rum Ayat 41 Dengan Pelestarian Lingkungan Pada Mapel Biologi Materi

Suaryana, Agung. "Implementasi akuntansi sosial dan lingkungan di Indonesia." Jurnal Ilmiah Akuntansi dan Bisnis (2011).

Siregar, Edy Batara Mulya. "Pencemaran udara, respon tanaman dan pengaruhnya pada manusia." Pencemaran Udara, Respon Tanaman Dan Pengaruhnya Pada Manusia (2005).

Sugandhy, Aca, And Rustam Hakim. Prinsip Dasar Kebijakan Pembangunan Berkelanjutan Berwawasan Lingkungan. Bumi Aksara, 2007.

Siahaan, Nommy Horas Thombang. Hukum Lingkungan Dan Ekologi Pembangunan. Erlangga, 2004.

Q.S. Ar-Rum Ayat 41-42

Q.S. Ar-Rum Ayat 41-42

Q.S.Al-A'raf Ayat 56-58

Q.S.Al-A'raf Ayat 56-58

Q.S. Sad Ayat 27

Q.S. Sad Ayat 2 